\section{Physicochemical characteristics and behavior of the serpentinous peridotite outcrops of San Jose and New Idria (California, USA) upon heating treatment}

Dr. Nshan ZULUMYAN

(1946) is chemist, graduated in 1971 at Yereva State University. He is head of laboratory and the assistant director at the Institute of Genera and Inorganic Chemistry of National Academy of Sciences of Republic of Armenia. He has about 80 scientific published works devoted to serpentinites processing, the research of serpentine structure features, the investigation of $\mathrm{Si}-\mathrm{O}$ bonds in serpentinite and other different silicate compounds, mechanochemical activation, corundum and silicon synthesis.

NshAN H. ZULUMYAN - Institute of General and Inorganic Chemistry of National Academy of Sciences of Republic of Armenia - Zulumnshan@rambler.ru

ANNA R. ISAHAKYAN - Institute of General and Inorganic Chemistry of National Academy of Sciences of Republic of Armenia - Isahakyananna@yahoo.com

HAYK A. BEGLARYAN - Institute of General and Inorganic Chemistry of National Academy of Sciences of Republic of Armenia • Hayk_b@mail.ru

Received: 21.12.2009. - Érkezett: 2009.12.21. http://dx.doi.org/10.14382/epitoanyag-jsbcm.2010.11

The iron magnesia ultra basic serpentinous rocks of San Jose and New Idria (California, USA) have been subjected to physicochemical analysis. Changes in the material's characteristics and behavior as a result of heat treatment have been investigated and quantified by using macro- and microscopic, X-ray and differential thermal analysis. Differences in response to heat treatment were seen for the various samples and could be correlated with the distribution of the ortho- and metasilicate anions participating in the formation of the serpentine silicate lattice (SSL) under hydrothermal conditions. The latter depends on the abundance of the starting minerals in the parent ultra basic rock.

Keywords: serpentinous peridotite, serpentine silicate lattice, silicate anion, $\mathrm{Si}-\mathrm{O}$ bond
Dr. Anna ISAHAKYAN

(1966) is engineer-chemist-technologist, graduated in 1989 at Yerevan State Polytechnic Institute with honours and got degree with distinction. She is going to become a PhD. She is scientific associate at the Institute of Genera and Inorganic Chemistry of National Academy of Sciences of Republic of Armenia. She has about 20 scientific published works devoted to serpentinites processing, the research of serpentine structure features, mechanochemica activation, corundum and silicon synthesis.

Dr. Hayk BEGLARYAN

(1982) is chemist, graduated in 2005 at Yerevan State University. He is scientific associate the Institute of General and Inorganic Chemistry of National Academy of Sciences of Republic of Armenia and a lecturer at the Yerevan State University. He has about 14 scientific published works devoted to chemical transport reactions and the research of serpentine structure.

\section{Introduction}

Recently a new approach to the thermoacid treatment of serpentinites has opened insights related to the possible use of such rocks $[1,2]$. The new approach involves the movement into solution of $\left(\mathrm{SiO}_{4}\right)^{4-}$ orthosilicate anions partitioned from SSL in the form of orthosilicic acid. This has two important implications for serpentinous ultra basic rocks.

First, it provides an avenue that allows one to study and better understand the mechanism and process of serpentine formation under hydrothermal conditions (and some other secondary minerals in our opinion). In other words, it provides an insight into the form and the state of the parent rocks prior to serpentinization. When combined with various physical measurements it provides information about the allocation and the quantity of ortho- and metasilicate anions participating in the formation of the SSL. The latter allows one to differentiate serpentinites according to the character and the behavior of silicate lattice and to try to find an application for serpentinites based on the details of the SSL.

Second, it provides an environmentally friendly, costeffective, technically achievable, and practical approach for the complex processing of the above-mentioned rocks. This method will allow one to obtain compounds of magnesium and iron with high yields and also light silica and aqua silica gels with unique physicochemical properties [3-7]. Following the aforementioned processing, the residue will be rich in compounds of chrome, cobalt, nickel, etc., which could be extracted with further processing. The quality and quantity of the unreacted residue will be dependent on the properties of the parent rock and its degree of serpentinization.
On the one hand, the work done will add to the geological knowledge about these rocks, while on the other hand, it will allow selection of the appropriate rock processing parameters for industry.

To date, only a limited number of ultrabasic rocks samples taken from different deposits in Armenia (mainly apodunite serpentines) have been investigated using the thermoacid treatment in conjunction with other physicochemical methods [8]. The results of these investigations have shown that the success of any thermoacid treatment of serpentinites by industry will be highly dependent on the "genetics" of their silicate lattice (SL), while the mineral morphology will play only a minor role [9].

The results of the analogous studies of peridotite serpentinite samples from San Jose (SJ-1, SJ-2) and New Idria (NI-1) (California, USA) deposits are given in this article [10, 11].

The present article reports the results of a physicochemical investigation of the SJ-1, SJ-2 and NI-1 samples. By comparing the results of these new samples with those previously determined for the Armenian samples we will attempt to draw conclusions about the silicon lattice structure based on the quantity and relative concentrations of ortho- and metasilicate anions.

\section{Experimental}

Original mineral serpentine from locality San Jose and New Idria (California, USA) was used. The chemical composition of serpentine power was determined by a chemical analysis. 
The milling process was carried out in a ball mill with a heat steel chamber. The phase analysis was performed by X-ray diffraction (XRD) with $\mathrm{Cu} \mathrm{K}_{\alpha}$ radiation. A Diffractometer Model DRON-3 was used. The differential thermal analysis and thermogravimetric analysis were performed in a MOM Q 1500D derivatograph with a heating rate of $10^{\circ} \mathrm{C} / \mathrm{min}$, an air atmosphere, a sample weight of $300 \mathrm{mg}$ and a maximum temperature of $1000^{\circ} \mathrm{C}$.

\section{Results and discussion}

The results of chemical analysis of the SJ-1, SJ-2 and NI-1 samples are given in Table 1 . As we are primarily interested in the $\mathrm{MgO}, \mathrm{SiO}_{2}$, and volatile content of the rocks, the chemical analysis did not attempt to differentiate the other individual metal oxides, but instead we just give their total amount $\left(\mathrm{R}_{2} \mathrm{O}_{3}\right)$.

\begin{tabular}{ccccccc}
$\begin{array}{c}\text { Samp- } \\
\text { les }\end{array}$ & \multicolumn{7}{c}{$\begin{array}{c}\text { Components and their } \\
\text { wt. percentage (\%) }\end{array}$} \\
$\mathbf{S i O}_{\mathbf{2}}$ & $\mathbf{R}_{\mathbf{2}} \mathbf{O}_{\mathbf{3}}$ & MgO & $\begin{array}{c}\text { Vola- } \\
\text { tiles }\end{array}$ & & SUM & $\begin{array}{c}\text { moles MgO } \\
\text { moles SiO }\end{array}$ \\
SJ-1 & 38.58 & 10.93 & 35.72 & 14.50 & 99.73 & 1.38 \\
\hline SJ-2 & 39.38 & 10.06 & 35.97 & 14.76 & 99.67 & 1.36 \\
\hline NI-1 & 37.11 & 13.94 & 34.84 & 13.60 & 99.49 & 1.40 \\
\hline SH-3* $^{*}$ & 36.28 & 9.51 & 37.37 & 14.93 & 98.09 & 1.54 \\
\hline
\end{tabular}

${ }^{*}$ For comparison, the values for sample SH-3, an Armenian lizardite apodunite [12] with a low antigorite content are given.

Table 1. The chemical analysis results of the researched samples

1. táblázat A vizsgált minták kémiai összetétele

Visual examination of the samples shows them all to be a finegrained, compact, schistose mass of the black and green-gray color. Through the microscope the samples clearly appear to be composed of various serpentine minerals with the lizardite variety dominating. All the samples can be considered to be apoperidotite serpentinite.

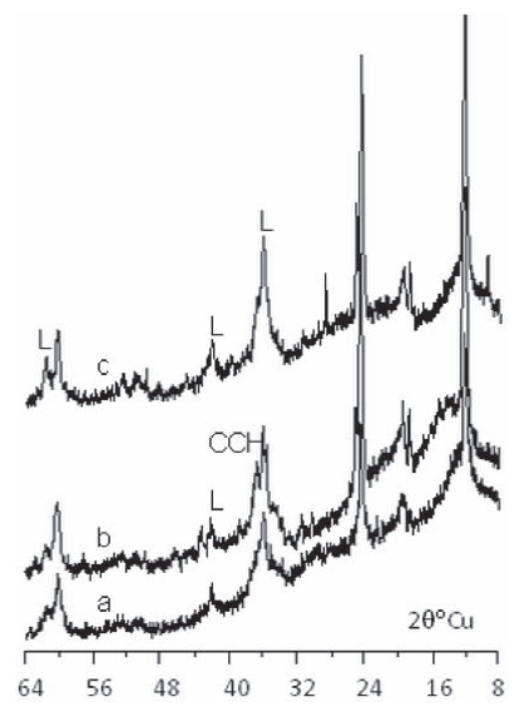

Fig.1. The X-ray powder diffraction patterns of the apoperidotite serpentinites: a-SJ-I, b-SJ-2; c-NI-1. L- lizardite, CCH - clinochrysotile

1. ábra Apoperidodites szerpentinek röntgen pordiffraktogramjai: $a-S J-I, b-S J-2$, c-NI-1, L - lizardit, CCH - klinokrizolit
The XRD analysis of the samples (Fig. 1.) also points to the predominance of lizardite in these samples. In addition the sample SJ-2 contains a tangible amount of clinochrysotile, and the others-mainly orthochrysotile. Lizardite is also partially present in the all paterns ${ }^{1^{*}}$.

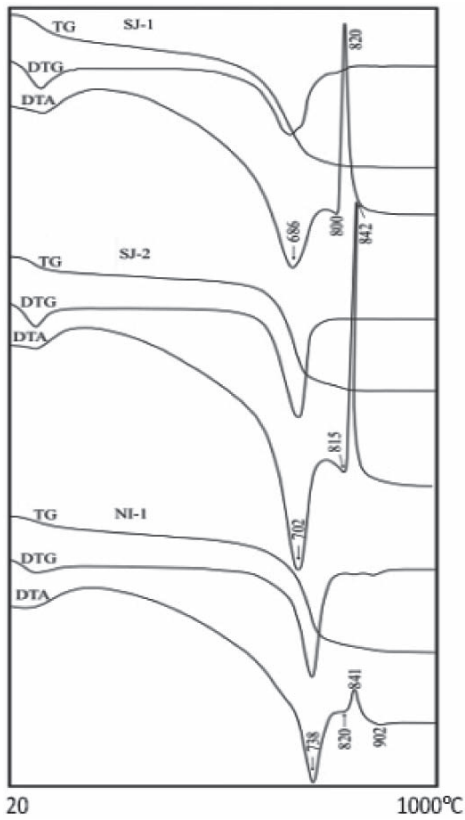

Fig. 2. Differential thermal curves for the apoperidotite serpentinite samples: $a-S J-1, b-S J-2, c-N I-1 . T G=$ Thermo gravimetric or weight loss curve, $D T G=$ Differential Thermo gravimetric curve (the derivative of the TG curve), DTA = Differential Thermal Analysis curve. The vertical axis label applies to the DTA curve

2. ábra Apoperidodites szerpentin minták differenciális termikus görbéi: a-SJ-I, b-SJ-2, c-NI-1 TG - termogravimetriás vagy tömegveszteségi görbe, DTG differenciális termogravimetriás görbe (a TG görbe deriváltja),

DTA - differenciális termikus analizis görbe. A függőleges tengely beosztása a DTA görbére vonatkozik.

In spite of the similar $\mathrm{SiO}_{2}$ and $\mathrm{MgO}$ content and overall composition of all the samples, their behavior is different upon heating. As seen in the differential thermal analysis (DTA) curves in Fig. 2. (a, b) for the SJ-1 and SJ-2 samples, intense endothermic and exothermic events occur. However, the curves for the two samples have different peak locations, shapes, and magnitudes. The sample SJ-1 differential thermal analysis (DTA) curve has two maxima (the higher temperature one is observed in the form of a shoulder). The analogous curve for the NI-1 sample differs from the previous ones in having a higher temperature location for the endothermic "peak" and much lower endothermic and exothermic peak intensity.

The X-ray diffraction patterns for the SJ-1, SJ-2 and NI-1 specimens heat-treated at temperatures from $600{ }^{\circ} \mathrm{C}$ to $850^{\circ} \mathrm{C}$ also have some distinctive features (Fig. 3-5.). For the SJ-1 and SJ-2 samples, the serpentine decomposition starts at lower temperatures than for the NI-1 sample (Fig. 3a; 4a; 5a). Also, the decomposition process for the SJ-1 and SJ-2 samples results in the formation of very little forsterite until temperatures of at least $750^{\circ} \mathrm{C}$. For the NI- 1 sample, the forsterite formation begins at the lower temperature where the serpentine decomposition begins.

\footnotetext{
1 "In Coleman's commentary all the patterns were characterized in a general way.
} 


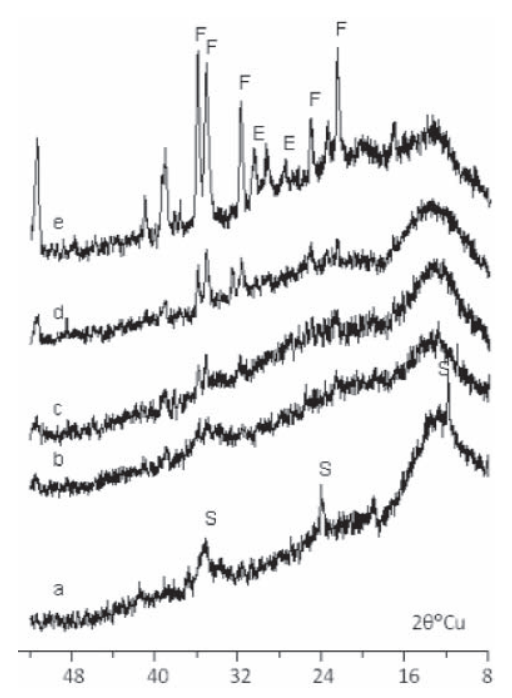

Fig. 3. The X-ray powder diffraction patterns of the SJ-1 heat-treated at the temperatures: $a-600$ ${ }^{\circ} \mathrm{C} ; b-650{ }^{\circ} \mathrm{C} ; c-700{ }^{\circ} \mathrm{C} ; d-750{ }^{\circ} \mathrm{C}$; $e-850^{\circ} \mathrm{C}$. S - serpentine; $F$ - forsterite; E-enstatite

3. ábra Különböző hőmérsékleteken kezelt SJ-I minta röntgen pordiffraktogramjai: $a-600^{\circ} \mathrm{C} ; b$ $-650^{\circ} \mathrm{C} ; \mathrm{C}-700^{\circ} \mathrm{C} ; \mathrm{d}-750^{\circ} \mathrm{C} ; e-850^{\circ} \mathrm{C}$. $S$ - szerpentin, $F$ - forszterit, $E$ - entsztatit

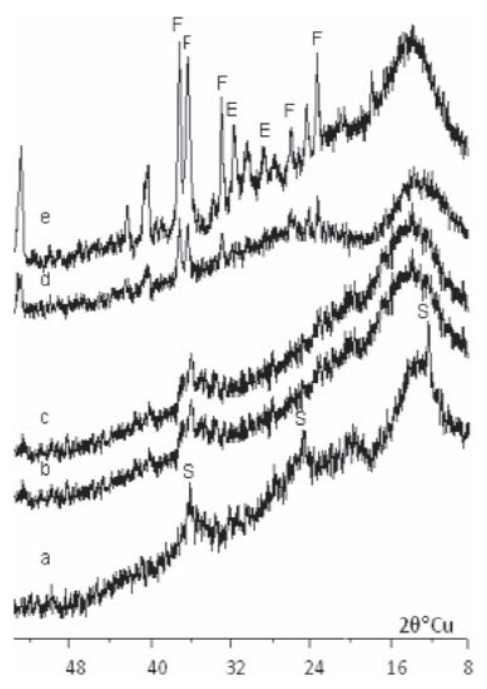

Fig. 4. The X-ray powder diffraction patterns of the SJ-2 heat-treated at the temperatures: $a-600$ ${ }^{\circ} \mathrm{C} ; b-650{ }^{\circ} \mathrm{C} ; c-700{ }^{\circ} \mathrm{C} ; d-750{ }^{\circ} \mathrm{C}$; $e-850^{\circ} \mathrm{C} . \mathrm{S}-$ serpentine; $F$ - forsterite; E- enstatite

4. ábra Különböző hömérsékleteken kezelt SJ-2 minta röntgen pordiffraktogramjai: $a-600^{\circ} \mathrm{C} ; b$ $-650{ }^{\circ} \mathrm{C} ; \mathrm{c}-700{ }^{\circ} \mathrm{C} ; d-750{ }^{\circ} \mathrm{C} ; e-850{ }^{\circ} \mathrm{C}$ $S$ - szerpentin, $F$ - forszterit, $E$ - entsztatit

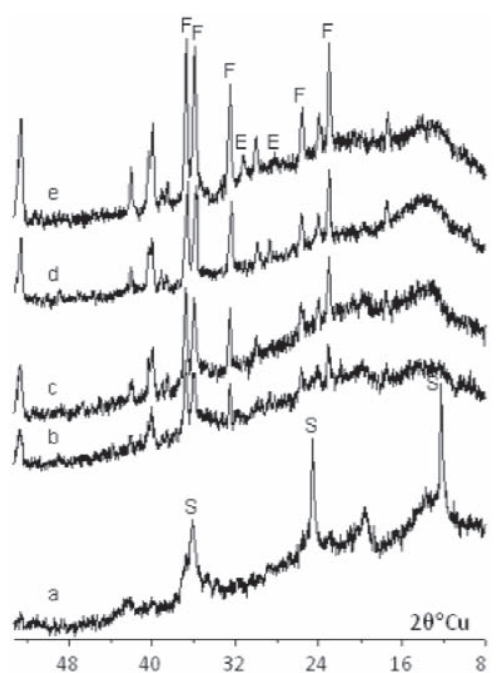

Fig. 5. The X-ray powder diffraction patterns of the NI-1 heat-treated at the temperatures: $a-600$ ${ }^{\circ} \mathrm{C} ; b-650{ }^{\circ} \mathrm{C} ; \mathrm{c}-700{ }^{\circ} \mathrm{C} ; \mathrm{d}-750{ }^{\circ} \mathrm{C}$; $e-850^{\circ} \mathrm{C} . \mathrm{S}$ - serpentine; $\mathrm{F}$ - forsterite; E- enstatite

5. ábra Különbözö hömérsékleteken kezelt NI-1 minta röntgen pordiffraktogramjai: $a-600^{\circ} \mathrm{C} ; b$ $-650{ }^{\circ} \mathrm{C} ; \mathrm{C}-700^{\circ} \mathrm{C} ; \mathrm{d}-750^{\circ} \mathrm{C} ; e-850^{\circ} \mathrm{C}$. $S$ - szerpentin, F-forszterit, $E$ - entsztatit
By comparing the X-ray diffraction data and the results of the differential thermal analysis of the heat-treated samples we conclude that the endothermic effects curves of the SJ-1 and SJ-2 samples are more intense since they are the result of the two endothermic effects: the removal of constitutional water and the decomposition of most of the SSL, neither of which are not compensated for by the exothermic formation of forsterite and/or enstatite. In this case the recrystallization of the lattice into forsterite does not begin until the SSL is nearly completely broken down. The less intense nature of the analogous curve for the NI-1 sample is likely to be due to the overlap of the two endothermic effects with the exothermic forsterite formation. In fact, for the NI-1 sample, the removal of constitutional water may be accompanied by the nearly simultaneous rearrangement of the SSL into the forsterite lattice.

The results of numerous experiments suggest that in the temperature range of $600-750{ }^{\circ} \mathrm{C}$ the formation of forsterite starts in one of two ways. The route chosen depends on the location of the $\left(\mathrm{SiO}_{4}\right)^{4-}$ anions. It is the author's opinion that in this temperature range forsterite formation is predominantly the result of the migration of a certain number of orthosilicate anions that are located side by side. However, all the metasilicate anions which are surrounded by $\left(\mathrm{SiO}_{4}\right)^{4-}$ anions cannot be involved in the formation of enstatite. At higher temperatures the formation of forsterite can be explained by the migration and bonding of $\mathrm{Mg}^{2+}$ and $\left(\mathrm{SiO}_{4}\right)^{4-}$ ions. The migration of the $\left(\mathrm{SiO}_{4}\right)^{4-}$ anions allows the formation of enstatite by releasing the metasilicate anions. Thus the degree of decomposition of the SSL and the number of metasilicate anions can be judged from the amount of the enstatite formed at the temperature $850^{\circ} \mathrm{C}$ and by its increase at higher temperature. By combining the determination of the fractional enstatite and forsterite formation at temperatures between $600{ }^{\circ} \mathrm{C}$ and $850{ }^{\circ} \mathrm{C}$ from $\mathrm{X}$-ray diffraction data with the results of the differential thermal analysis (DTA) at temperatures below $850{ }^{\circ} \mathrm{C}$ it is possible to determine the number and location of the $\left(\mathrm{SiO}_{4}\right)^{4-}$ and $\left[\left(\mathrm{SiO}_{3}\right)^{2-}\right]_{\mathrm{n}}$ anions in the SSL.

The above argument is based on the formation of new $\mathrm{Si}-\mathrm{O}$ bonds that result as the parent silicate rock is transformed into serpentine under hydrothermal conditions. These newly formed $\mathrm{Si}-\mathrm{O}$ are thought to be weaker than the standard $\mathrm{Si}-\mathrm{O}$ and $\mathrm{Si}-\mathrm{O}-\mathrm{Si}$ bonds formed by ortho- and metasilicate anions that remain from the parent material. In other words, during the initial formation of the SSL under hydrothermal conditions at temperature below about $500{ }^{\circ} \mathrm{C}$ [13], the newly formed $\mathrm{Si}-\mathrm{O}$ bonds yield to the original $\mathrm{Si}-\mathrm{O}$ and $\mathrm{Si}-\mathrm{O}-\mathrm{Si}$ bonds of the parent rock from which the serpentine formed. This leaves isolated tetrahedrons and metasilicate anions in the resulting "lattice" which are only weakly bound because of the absence of full $\pi$-bonds that result from the free $d$ - orbital of silicon and the unshared electron pair of oxygen [14].

The above promotes the cutting of the newly formed bonds during heat treatment. Therefore the initial number of the orthoand metasilicate anions participating in the SSL formation mainly predetermines the quantity of the partitioned versus "free" orthosilicate anions that results from the heat treatment of serpentines. Evidence for this comes from the fact that after thermo acid treatment of the serpentinites which were formed from pyroxenites, the amount of orthosilicic acid released into solution is several times less than that for apodunite serpentinites [9] which were subjected to the same treatment. In other words, for heat-treated serpentinites, the combination of the initial temperature of forsterite formation and its dynamics as a function of temperature below $850{ }^{\circ} \mathrm{C}$ allows one to determine the approximate proportion and allocation of the ortho- and metasilicate anions that participated in the SSL formation. 


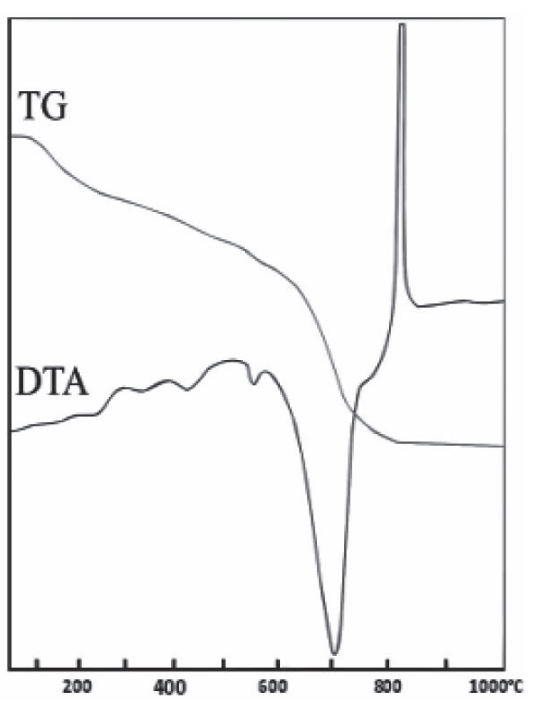

Fig. 6. Differential thermal curves for the apodunite serpentinite sample Sh-3. TG = Thermo gravimetric or weight loss curve, DTA $=$ Differential Thermal Analysis curve. The vertical axis label applies to the DTA curve

6. ábra AzSh-3 jelü, apodunit szerpentin minta DTG görbéi. TG - termogravimetriás vagy tömegveszteségi görbe, DTA - differenciális termikus analizis görbe. A függőleges tengely beosztása a DTA görbére vonatkozik

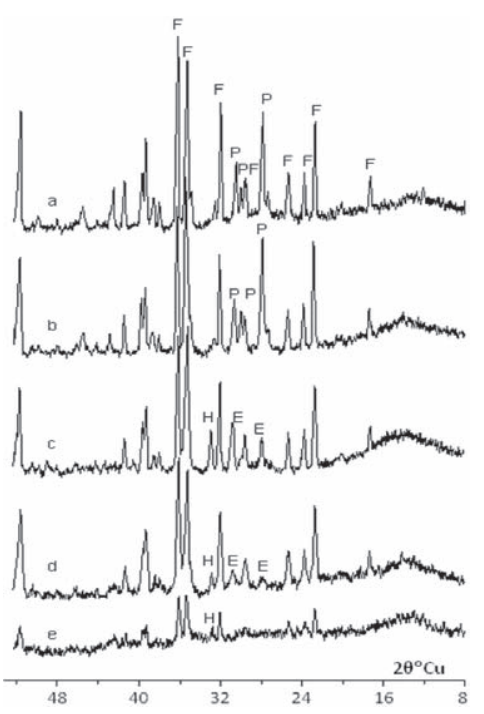

Fig. 7. The X-ray powder diffraction patterns of the Sh-3 heat-treated at the temperatures: $a-$ $1260{ }^{\circ} \mathrm{C} ; b-1160{ }^{\circ} \mathrm{C} ; \mathrm{c}-1000{ }^{\circ} \mathrm{C} ; d-850$ ${ }^{\circ} \mathrm{C} ; e-680{ }^{\circ} \mathrm{C} . \mathrm{F}$ - forsterite; $\mathrm{E}$ - enstatite; $H$-hematite; $P$ - protoenstatite

7. ábra Különböző hömérsékleteken kezelt Sh-3 minta röntgen pordiffraktogramjai: $a-1260$ ${ }^{\circ} \mathrm{C} ; b-1160{ }^{\circ} \mathrm{C} ; \mathrm{c}-1000{ }^{\circ} \mathrm{C} ; d-850^{\circ} \mathrm{C}$; e $-680^{\circ} \mathrm{C} . \mathrm{F}$ - forszterit, $\mathrm{E}$ - entsztatit, $\mathrm{H}$ hematit, $P$ - protoensztatit

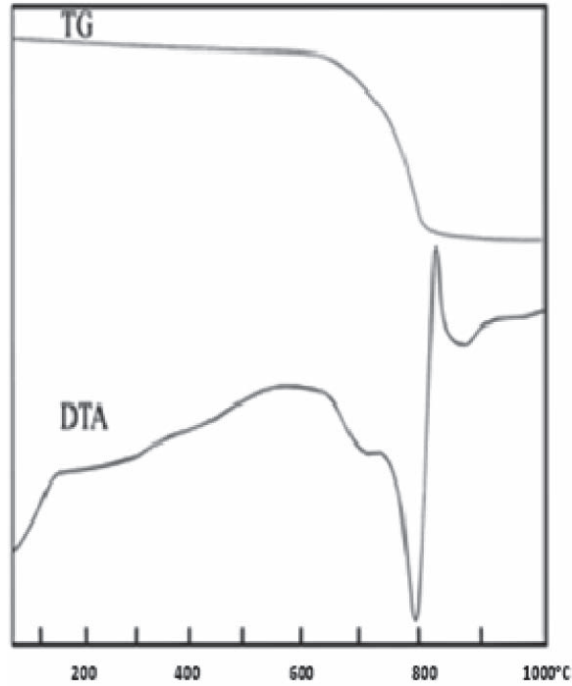

Fig. 8. Differential thermal curves for the apopyroxenite serpentine sample $4147 \mathrm{~B}$. TG $=$ Thermo gravimetric or weight loss curve, DTA $=$ Differential Thermal Analysis curve. The vertical axis label applies to the DTA curve

8. ábra A hökezelt 4147B jelü apopiroxenit minta DTA görbéi. TG - termogravimetriás vagy tömegveszteségi görbe, DTA - differenciális termikus analizis görbe. A függöleges tengely beosztása a DTA görbére vonatkozik
Let us now consider several variants of the formation of the SSL and the behavior of the resulting serpentinites upon heating.

1. Apodunite serpentine: in this case great number of $\left(\mathrm{SiO}_{4}\right)^{4-}$ anions must participate in forming the SSL. It is natural to suppose that during the thermal decomposition of this serpentine, the breakdown of the SSL proceeds by rupturing a great number of the new bonds that formed during the serpentine formation. The result is number of $\left(\mathrm{SiO}_{4}\right)^{4-}$ anions that are side-by-side which can immediately form forsterite. However, at temperature below $800{ }^{\circ} \mathrm{C}$ the majority of the released $\left(\mathrm{SiO}_{4}\right)^{4-}$ anions remain partitioned. At temperatures above $800{ }^{\circ} \mathrm{C}$ these become highly mobile allowing forsterite formation to proceed rapidly. The evidence for this process is the intensive exothermic peak on the DTA curve (Fig. 6.) and in the X-ray powder diffraction patterns (Fig. 7.) of the Sh-3 sample, which is an Armenian lizardite apodunite.

2. Apopyroxenite serpentine: here a great number of $\left[\left(\mathrm{SiO}_{3}\right)^{2-}\right]_{\mathrm{n}}$ anions participate in the SSL formation. During the thermal decomposition of the SSL these $\left[\left(\mathrm{SiO}_{3}\right)^{2-}\right]_{\mathrm{n}}$ anions will be released. For this serpentine, the forsterite formation is observed only at temperatures higher than $750{ }^{\circ} \mathrm{C}$ and strong endothermic and weak exothermic peaks are seen in the DTA curve. The latter is the result of the formation of both forsterite and enstatite, with the weakness of the exothermic peak being due to the small number of free $\left(\mathrm{SiO}_{4}\right)^{4-}$ anions present. A previous investigation of an apopyroxenite serpentine showed that significant amounts of enstatite are already observed at the temperature of $750{ }^{\circ} \mathrm{C}$ in the XRD graphs. It's clearly seen on the DTA curves (Fig. 8.) and in the X-ray powder diffraction patterns (Fig. 9.) of the Armenian sample 4147B, which is an apopyroxenite serpentine.
3. Apoperidotite serpentine: this form of serpentinite is characterized by a range of behavior which depends on the allocation of the $\left(\mathrm{SiO}_{4}\right)^{4-}$ and $\left[\left(\mathrm{SiO}_{3}\right)^{2-}\right]_{n}$ anions participating in the SSL formation and their initial coordination. Let us consider one of the possible variants where we assume we have a comparable quantity of $\left(\mathrm{SiO}_{4}\right)^{4-}$ and $\left[\left(\mathrm{SiO}_{3}\right)^{2-}\right]_{\mathrm{n}}$ anions participated in the SSL formation. Even here there are at least two different possible behaviors that result from the heating of the serpentine: a) There is an even distribution of the abovementioned anions throughout the SSL: in this case, due to the required migration of the $\left(\mathrm{SiO}_{4}\right)^{4-}$ anions, the forsterite formation only begins at temperatures in excess of $750{ }^{\circ} \mathrm{C}$. The initial stage of the serpentine decomposition is impeded by the shortage of $\left(\mathrm{SiO}_{4}\right)^{4-}$ anions which are located side by side (for example, for the SJ-1 and SJ-2samples); b) There is an equal allocation but non-uniform distribution of $\left(\mathrm{SiO}_{4}\right)^{4-}$ and $\left[\left(\mathrm{SiO}_{3}\right)^{2-}\right]_{\mathrm{n}}$ anions: in this case because a considerable quantity of $\left(\mathrm{SiO}_{4}\right)^{4-}$ anions will be located side by side, the exothermic forsterite formation and endothermic SSL decomposition can proceed simultaneously thereby largely compensating one's heat release by the other's heat requirement. The result is the observation of a less intense endothermic peak as well as a less intense exothermic peak (for example, for the NI-1 sample). The above effect is also expected to cause the decomposition to begin at lower temperatures. Thus at temperatures higher than $750{ }^{\circ} \mathrm{C}$ only a small quantity of $\left(\mathrm{SiO}_{4}\right)^{4-}$ anions is expected to remain, resulting in a smaller exothermic forsterite peak at these higher temperatures. This effect is observed in the DTA curve of Fig. 2. (b).

It should be noted that since both the enstatite and forsterite formation reactions are exothermic, both will contribute to the exothermic peak seen. (On a per gram basis, thermodynamic 
data indicate that the exothermicity of forsterite formation is about $1 / 3$ greater than that of enstatite formation.) The existence of both enstatite and forsterite is seen in the XRD analysis of the samples annealed at the temperature $850{ }^{\circ} \mathrm{C}$ (Fig. 3. (e); Fig. 4. (e); Fig. 5. (e)).

From the above, it is evident that one will only be able to predict the behavior and the ability to potentially utilize a given serpentinite sample by a combination of differential thermal, $\mathrm{XRD}$ and chemical analysis.

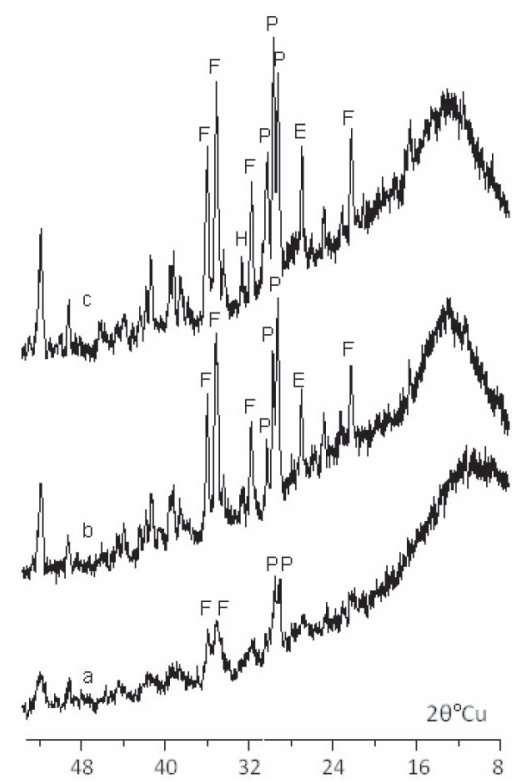

Fig. 9. The X-ray powder diffraction patterns of the $4147 \mathrm{~B}$ heat-treated at the temperatures: $a-650^{\circ} \mathrm{C} ; b-720^{\circ} \mathrm{C} ; \mathrm{C}-850^{\circ} \mathrm{C}$. F-forsterite; E- enstatite; $P$ - pyroxene; $H$ - hematite

9. ábra A különbözö hömérsékleteken kezelt $4147 B$ minta röntgen pordiffraktogram jai: $a-650{ }^{\circ} \mathrm{C} ; b-720^{\circ} \mathrm{C} ; c-850{ }^{\circ} \mathrm{C}$. F - forszterit, E-entsztatit, $P$ - piroxén, $H$ - hematit

\section{Conclusions}

1. In case of the SJ-1 and SJ-2 heat-treated serpentinite samples, the bulk of the forsterite only begins forming at temperatures above $750{ }^{\circ} \mathrm{C}$ and this process is being accompanied by a large exothermic peak in the DTA curve.

2. In case of the NI-1 heat-treated serpentinite sample, noticeable amounts of forsterite already appear at a temperature of $650{ }^{\circ} \mathrm{C}$ and this process is simultaneously accompanied by the SSL decomposition. As a result, the endo- and exothermic peaks in the DTA curve are not very intense.

3. The SJ-1, SJ-2 and NI-1 samples which are all apoperidotite serpentinites are characterized by different behaviors which depend on the relative allocation of ortho- and metasilicate anions and their distribution within the SSL. The samples SJ-1 and SJ-2 SL are characterized by a more uniform distribution of anions than in the NI-1sample.

\section{Acknowledgment}

Authors are very grateful to Dr. Robert G. Coleman for providing the SJ-1, SJ-2 and NI-1 samples and information about them.

\section{References}

[1] Zulumyan, N. - Isahakyan, A. - Hovhannisyan, Z.: A new promising method for processing of serpentinites, Rus. J. of Appl. Chem., Vol. 80, No. 6, pp. 1020-1022. DOI: 10.1134/S1070427207060353 (2007).

[2] Patent RA 1339 A2, 2003.

[3] Patent RA 1536 A2, 2004.

[4] Patent RA 1576 A2, 2005.

[5] Avetisyan, A. - Gevorgyan, A. - Harutyunyan, A. - Pirumyan, G. Zulumyan, N.: New methods of wastewater purification, World Water and Environmental Resources Congress 2005: Impacts of Global Climate Change, Anchovag, USA, May 15-19, pp.437-440 (2005).

[6] Zulumyan, N. - Torosyan, A. - Hovhannisyan, Z. - Ghazaryan, S.: The Influence of Mechanical Processing on the Process of Thermal Reduction of $\mathrm{SiO}_{2}$ by $\mathrm{Al}$ and Characterization of the Formed $\mathrm{Si}_{-} \mathrm{Al}_{2} \mathrm{O}_{3}$ Powdered and Compacted Composites, TMS 2005 Annual Meeting \& Exhibition, 13-17 February, San Francisco, California, USA, pp.779-785 (2005).

[7] Torosyan, A. - Takacs, L. - Zulumyan, N. - Tataryan, A.: Mechanically Induced Modification of an Al Surface and the Synthesis of Ceramic Coatings by Milling in $\mathrm{SiO}_{2}$ Particles, TMS 2005 Annual Meeting \& Exhibition, 1317 February, San Francisco, California, USA, pp. 121-126 (2005).

[8] S. Abovyan: Geology and the minerals of the northeastern coast of Lake Sevan. NAS RA, Yerevan, 1961.

[9] Zulumyan, N. - Abovyan, S. - Hovhannisyan, Z. - Ghazaryan, S.: Problems on development of serpentine-forming processes in ultramafics, Sciences about the Earth, NAS RA, 56(3), pp. 29-34 (2003).

[10] Coleman, R.: New Idria Serpentinite: A Land Management Dilemma, Environmental \& Engineering Geoscience, 2(1), pp. 9-22 (1996).

[11] Coleman, R.: Prospecting for ophiolites along the California continental margin, Geological Society of America Special Paper 349, pp. 351--364 (2000).

[12] Zulumyan, N. - Hovhannisyan, Z. - Karakhanyan, S.: Physicochemical character of the several ultra basic rocks of the northeastern coast of the lake Sevan, Chem. J. of Armenia, 55(4), pp. 33-41 (2002).

[13] Deer, W. - Howie, R., - Zussman, J.: Rock-forming minerals. V. 3, London, 1962.

[14] Akhmetov, N.: Inorganic chemistry. High school, Moscow, 1975.

San Jose-ből és New Idria-ból (Kalifornia, USA) származó szerpentines periodit rétegkibukkanások fizikai-kémiai jellemzői és hőkezelés közbeni viselkedése

San-Jose-ból és New Idria-ból származó, vas- és magnéziumoxid tartalmú, ultra-bázikus szerpentin kôzetek fizikai-kémiai jellemzôit vizsgáltuk. Tanulmányoztuk az anyagi jellemzốk változásait és a hôkezelés közbeni viselkedést. A mennyiségi adatok meghatározásához makro- és mikroszkópos vizsgálatokat, röntgen-diffrakciós fáziselemzéseket és differenciális termikus elemzéseket végeztünk. A különbözố minták hôkezelés során különbözôképpen viselkedtek. A termikus viselkedés azon orto- és metaszilikát anionok eloszlásával függött össze, amelyek a szerpentin szilikát rács (SSL) hidrotermális körülmények közötti kialakulásában fontos szerepet játszottak. A kialakulási folyamat függ a megfelelô ultra-bázikus kốzetekben jelenlevố ásványok gyakoriságától.

Kulcsszavak: szerpentines periodit, szerpentin szilikát rács, szilikát anion, Si-O kötés

Ref.: http://dx.doi.org//10.14382/epitoanyag-jsbcm.2010.11

Zulumyan, N. H. - Isahakyan, A. R. - Beglaryan, H. A.: Physicochemical characteristics and behavior of the serpentinous peridotite outcrops of San Jose and New Idria (California, USA) upon heating treatment. Építőanyag, 62. évf. 2. szám (2010), 50-54. p. 